\title{
ПІЗНАВАНІСТЬ СИМВОЛУ В МУЗИЦІ ІНТЕРПРЕТАТИВНИЙ АНАЛІЗ
}

\author{
Ніколаєвська Ю. В., Шаповалова Л. В.
}

\section{ВСТУП}

Сучасне музикознавство має у своєму розпорядженні органон наук, присвячений вивченню символу як одиниці західноєвропейської культури. Серед провідних напрямів - класична семіотика (Ч. Пірс, Ф. де Соссюр), психологія (К. Юнг), філософія (О. Лосєв, П. Флоренський), поетика літератури (Й. Гете, Ф. Шиллер, французькі й російські символісти), культурологія (Ц. Тодоров, С. Аверінцев) тощо. Узагальнення когнітивного досвіду вивчення художньої природи символу уможливлює вироблення інваріантної структури символу на грунті різних галузей гуманітаристики (богослов'я, літератури, філософії, культурології) і становить методологію для музикознавчих проекцій на матеріал музичної творчості. Це надзавдання визначає актуальність теми дослідження саме для сучасної музикології, у якій відбувається «інтерпретативний поворот». Принцип відбору різних наукових дефініцій зумовлений актуалізацією пізнаваності символу в музичній культурі як класико-романтичної (XVIII-XX ст., так i посткласичної доби (XX-XXI ст.), щоб у подальшому озброїти виконавців метанауковим підходом до інтерпретації символу в процесі музикування, сприйняття й дослідництва сенсів музики.

Мета дослідження - узагальнити когнітивний досвід вивчення художньої природи символу для застосування символології як спеціального методу виконавського мистецтва.

Музична семіотика в процесі розуміння не тільки знаку та символу, а й пізнання загалом, досі залишається актуальною в зарубіжному мистецтвознавстві. Так, із часів праць Ж. Ж.-Наттьєза ${ }^{1}$, 3. Лісси ${ }^{2}$, Д. Кука ${ }^{3}$, К. Бейєра ${ }^{4}$ у розробці перебувають питання смислоосягнення,

\footnotetext{
${ }^{1}$ Nattiez J.-J. Musicologie generale et semiologie. P. : Christian Bourgois, 1987. 400 p.

${ }^{2}$ Lissa Z. O tzw. rozumieniu muzyki. Nowe szkice $z$ estetyki muzycznei. Krakow, 1975. S. 26-52.

${ }^{3}$ Cooke D. The language of music. Oxford, 1959. $230 \mathrm{p}$.

${ }^{4}$ Beyer K., Eraser C. Speech as a marker of situation. Sosial markers in speech. Cambridge Paris, 1978. P. 33-62.
} 
можливостей семіотичного аналізу (М. Рейбрук ${ }^{5}$, Н. Міюз ${ }^{6}$, А. Бренд $\left.{ }^{7}\right)$, теорії музичної семіотики Е. Тарасті ${ }^{8}$ (1994). Як зазначено у Філософському словнику (2002), «в семіотиці символ розглядають як різновид багатозначного (іноді безкінечно-значущого) знака» ${ }^{9}$. Новітня філософія дійшла такого висновку: якщо символ завжди передбачає свідомість, то знак - «зупинку свідомості» (М. Мамардашвілі). Важливим $є$ твердження, що «за своєю природою символ тяжіє до діалогічної форми пізнання, оскільки зміст його може бути розкритий тільки в людському спілкуванні, за межами якого символ вироджується в порожню форму» ${ }^{10}$. Для музиканта це твердження - очевидна й абсолютна істина, оскільки розуміння музики відбувається лише за умови відкритості автора Іншому й, навпаки, виконавець і слухач єднаються навколо особистості свого композитора (автора) - творця духовної реальності музики, ії буття.

\section{1. Філософські засади дослідження символу як об'скта духовної культури}

Кожна епоха виявляла своє розуміння символу, що було результатом розвитку в межах внутрішньої логіки конкретного історичного відтинку часу. Але найбільшу ясність і визначеність це слово набуло в період романтизму, який концентрує величезну кількість його смислів. Така, наприклад, позиція французького дослідника Ц. Тодорова, який небезпідставно вважає, що німецький філософ І. Кант в «Критиці здатності суджень», по суті, перевернув сенс слова «символ», який характеризує «не абстрактне розум, а властивий інтуїтивного й чуттєвого способу освоєння дійсності» ${ }^{11}$.

Теорія символу як складник сучасної гуманітаристики містить різні дефініції категорії «символ» в динаміці співвідношення різних аспектів розуміння смислотворення в мистецтві: символ як поняття й художня

${ }^{5}$ Reybrouck M. Music and Semiotics: An Experiential Approach to Musical SenseMaking. Interdisciplinary Approaches to Semiotics, Asuncion Lopez-Varela Azcarate, IntechOpen, 2017. URL: https://www.intechopen.com/books/interdisciplinaryapproaches-to-semiotics/music-and-semiotics-an-experiential-approach-to-musical-sensemaking (дата звернення 20.02.2021).

${ }^{6}$ Meeús N. A semiotic approach to music. Contemporary Music Review. 1993. V. 9. Is. 1-2 : Music and Cognitive Sciences. P. 305-310.

${ }^{7}$ BRANDT A., CARMO JR., JOSÉ R. MUSIC AND MEANING. SIGNATA. 2015. V. 6. P. 15-21. URL: HTTPS://DOI.ORG/10.4000/SIGNATA.1382 (ДATA ЗВЕРНЕННЯ 20.02.2021).

${ }^{8}$ Tarasti E. A Theory of Musical Semiotics. Indiana University Press, 1994. 352 p.

${ }^{9}$ Символ. Філософський енциклопедичний словник. Київ : Абрис 2002. С. 578.

${ }^{10}$ Там само. С. 579.

11 Тодоров Ц. Теории символа. Москва : Дом интеллектуальной книги, 1999. C. 233. 
реальність, символ як музично-слуховий феномен; функціонування релігійного символу. Розрізняються рівні пізнаваності символу у філософському дискурсі: а) причини появи (генеза) і призначення; б) структура символу; в) межі сенсу.

Теорії романтиків виходять із поетики мистецтва та на неї спрямовані. Тому «форма» символу орієнтована на мовне середовище: у ньому $є$ ідея, його сутність - тотожність протилежностей, але він створений і вимагає розуміння. Справедливою є думка С. Аверинцева щодо розуміння символу в Й.В. Гете, який «зв'язував невловимість $\mathrm{i}$ нероздільність символу ні 3 містичною потойбічною, а із життєвою органічністю, увиразнених через символ первнів» ${ }^{12}$. У Й.В. Гете можна запозичити узагальнення властивостей символу, а саме: символ виявляє себе як тип, зразок, приклад; він нетразинтивний і зорієнтований на сприйняття/розуміння; нарешті, він існує заради себе самого (звідси його лаконічність, щільність, стислість) і лише вторинним чином щось означає. Поета цікавив процес виробництва і сприйняття символів, власне, символ охарактеризований ним згідно з усіма вимогами i традиціями романтизму, у якому мистецтво мислиться виразником того, що не можна висловити ніяким іншим способом, того, що вислизає з мовної сутності вираження: «естетичної ідеї» (І. Кант), «таємничої речі» (Ф. Вакенродер), «божественного, суто духовного» (Ф. Шлегель).

3 нездатністю розуму повною мірою пізнати зміст символу пов'язані такі його властивості, як одночасність і моментальність; єднання протилежностей; спів-присутність функцій «існування» й «пояснення». За Ф. Шеллінгом, символ $\epsilon$ «нерозрізнена тотожність» загального й особливого, ідеального i реального, нескінченного i кінцевого, нарешті, ідеї і образу та характеризується тим, що не тільки «позначає», а й «має існуванням» ${ }^{13}$.

Уже в контексті сучасної теорії пізнання В. Ільїн розрізняє такі рівні пізнаваності символу (символічних форм мистецтва): інтерактивність (символічність засвідчується спілкуванням); трансреальність (бо символи переводять конкретне в абстрактне та індивідуальне в типове); над-індивідуальність (вихід за межі «самості»); виразність («мисляче мислить образами, за Аристотелем); над-ситуативність (якщо знак припускає зв'язок із часопростором, то символ - ні); герменевтичність (Людина, за М. Гайдеггером, розгортається за чотирма базовими символами як «інтерпретативними архетипами екзистенціальності»: порятунок землі, сприйняття неба, очікування божественного,

\footnotetext{
${ }^{12}$ Аверинцев С. Символ. Аверинцев С. София-Логос . Киев, 2001. С. 160.

${ }^{13}$ Шеллинг Ф. Философия искусства. Москва : Мысль, 1966. 496 с.
} 
проводжання смертного); багатозначність (плюралізм символічного $є$ наслідком його фундаментальності); спонукальність, духопід'ємність («людина $\epsilon$ ніколи не завершений імперфект» ${ }^{14}$ ); креативність (символ - завжди проектування дійсного на фон можливого, відкритого в нескінченність). Отже, виходячи 3 вищезазначеного, символ можна представити як смислову реалію (на відміну від знака, який позначає реалії). Символ, указує В. Ільїн, вкидає в предметні даності «надпредметний зміст» ${ }^{15}$.

Ще одна найцікавіша когнітивна ситуація навколо проблеми символу склалася у зв'язку з актуалізацією категорії «свідомість», 3 рухливістю й оборотністю зв'язку того, що означується, й означуваного. Вочевидь, це викликано впливами герменевтики, психоаналізу, богослов'я на збагачення окремих методологій (у тому числі музичної науки). Важливу особливість існування символу у $\mathrm{XX}$ столітті зазначив психолог I. Шкуратов ${ }^{16}$, уважаючи, що в сучасній науці символ $\epsilon$ представником біля-лінгвістичної (навіть домовленнєвої) сфери. Отже, крім того, що символ існує сам по собі, він ще й щось пояснює; його «зміст» вислизає від розуму, він здатний висловити те, що неможливо промовити; у кінцевому підсумку, розуміння символу пов'язано з чуттєвим та інтуїтивним сприйняттям. Важливо те, що романтики чітко встановлюють відношення «символ сприймання». Діяльність свідомості, яка сприймає, проводить межу між символом як поняттям i як явищем. Ще більш ця межа позначається в гуманітарних науках XX ст. Чаша терезів коливається між знаковою і над-знаковою природою символу, його мовною чи мовленнєвою сутністю вираження.

У другій половині XX ст. сформульовано ідею трансформації знаків у символи в досвід знання, що доводить думку, що ніяких символів не існує. М. Мамардашвілі та О. П'ятигорський пишуть: «Опинившись усередині наших знакових систем, символи переходять (переводять нас) із ситуації розуміння в ситуацію знання (активно діючого автоматичного режиму нашого індивідуального психічного механізму). Цим ми постійно зменшуємо кількість символів у зверненні й збільшуємо кількість знаків. По суті, багатющий досвід наукового семіотизації в культурі третьої чверті XX століття - це досвід перекладу символів свідомості в знаки культури» ${ }^{17}$. «Понятійність» символу та його зв'язок

${ }^{14}$ Шеллинг Ф. Философия искусства. Москва : Мысль, 1966. 496 с.

15 Там само. С. 36.

${ }_{17}^{16}$ Шкуратов В. Историческая психология. 2-е изд. Москва, 1997. 505 с.

${ }^{17}$ Мамардашвили М.К., Пятигорский А.М. Символ и сознание. Метафизические рассуждения о сознании, символике и языке. Москва : Языки русской культуры, 1997. C. 102. 
зі знаком обговорюються в дослідженні Л. Вітгенштейна, який уважав, що сам символ ніколи не дорівнює поняттю «символ»: «Будь-яке визначення символу не може нічого зробити, крім того, щоб бути доданим до символу. Наше розуміння символу полягає в тому, що воно виходить за свої межі до якоїсь тіньової суті, стоїть між символом і фактом, до тіні виконання, яка призначена для посередництва між символом і фактом» ${ }^{18}$. Автор робить висновок, що символ - знак, але такий знак, який завжди має сенс у майбутньому, перспективу (на відміну від знака, який може й не мати сенсу).

Чим відрізняються символи релігійні від інших символічних форм? П. Тілліх, аналізуючи мову релігії, ставить проблему знаків і символів на грунті систематизації релігійного досвіду ${ }^{19}$. Теолог зараховує саме існування форм і символів вираження в художній культурі до свідчень «туги за сакральним». Релігійні символи, указуючи на щось, що поза ними, роблять можливим для людської душі вимір і пізнання глибин сенсу. Важливою для нас є думка, що «релігійні символи виникають не тому, що виникає щось нове в дійсності Бога, а тому, що змінюється ставлення людини до основ Буття. Релігійні символи - символи святого, i їх істинність полягає в тому, що вони відповідають релігійної ситуації, у якій виникли» ${ }^{20}$. «Релігійна ситуація»- термін, що пояснює появу нових символів і втрату старих, породжений зміною ставлення людини до Бога (зміною досвіду!), яке відбивають релігійні символи. У свою чергу, ці символи уможливлюють пізнання незмірної глибини Божественного:

В Августина в трактаті, присвяченому теорії тлумачення християнських текстів і Святого Письма зазначено: «Сутність нашого дослідження полягає в розкритті тієї важливої істини, що повнота й мета закону всього Святого Письма $є$ любов (до того єдиного Предмета, яким має насолоджуватися)» ${ }^{21}$. Немає іншого предмета, крім Бога, гідного насолоди; іншими ж предметами (світом) необхідно користуватися для досягнення мети - пізнання Бога. У тому, що людина пізнає предмети за допомогою знаків, в Августина немає сумнівів. Усякий знак, за словами Августина, - це предмет, що збуджує, думка про те, що знаходиться за межами враження ${ }^{22}$. Отже,

18 Витгенштейн Л. Человек и мыслитель. Москва : Прогресс - Культура, 1993. С. 300.

19 Тиллих П. Теология культуры. Избранное: Теология культуры / пер. с англ. О. В. Боровой. Москва, 1995. С. 236-395.

${ }^{20}$ Там само. С. 261.

21 Августин Блаженный. Христианская наука или основания герменевтики и церковного красноречия. Киев, 1835 (репринт). С. 58.

${ }_{22}^{2}$ Там само. С. 67. 
філософ поставив проблему, що стала однією із засадничих, виразність Божественного (Бог - єдина сутність, яка абсолютно не $є$ знаком). Тому метою існування знака у світі $€$ таке: за допомогою видимих і чуттєвих речей (знаків) придбати пізнання про вічне i духовне («невидимий Божий світ»). Знак i його пізнання для Августина - шлях до осягнення «невидимого Божого». Унаочнимо механізми пізнання символу на рис. 1.

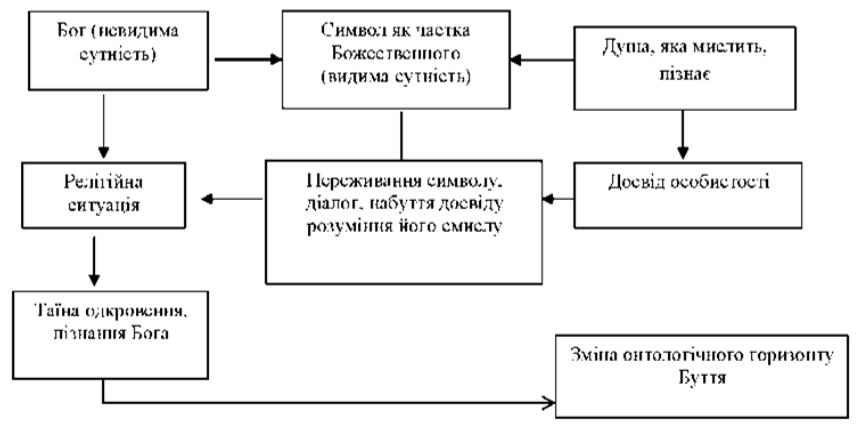

\section{Рис. 1. Механізми функціонування релігійного символу}

Великий вплив на трактування символу в мистецтві мав Г. Юнг, який $\mathrm{y}$ працях закцентував його смислову «додатковість»: «... символом ми називаємо термін, назву або навіть образ, що володіє особливим додатковим значенням, що несе щось невизначене, невідоме <...>, значення якого виходить за рамки прямого й не піддається точному визначенню та поясненню» ${ }^{23}$. Пояснюючи своє розуміння символу, Г. Юнг дає важливу установку: «Що є символ, що - ні, залежить передусім від установки свідомості. Те, що для когось зовсім не видається символічним, може видаватися таким свідомості іншої людини» ${ }^{24}$.

Класичним для вивчення символу як когнітивного інструменту аналізу музику постає визначення О. Лосєва. Учений пояснює символ речі: 1) як іiі сенс, який iï конструює і модельно породжує; 2) як узагальнення, яке вже містить у собі все, що усимволюється; 3) як закон, який у смисловий спосіб породжує речі, залишаючи недоторканою всю їх емпіричну конкретність; 4) як структуру,

\footnotetext{
${ }^{23}$ Юнг Г. Человек и его символы. Москва : Renais, 1991. C. 16.

${ }^{24}$ Юнг Г. Психологические типы. Москва, 1996. С. 557.
} 
заряджену нескінченністю проявів цієї структури; 5) як тотожність; 6) як якусь межу. Тож символ являє собою образну конструкцію, що вказує на межі небуття (у тому числі на безмежність). Як пише О. Лосєв, «не можна провести грань між кінцівкою і нескінченністю символу, бо, з одного боку, категорія символу всюди й завжди кінечна, 3 іншого - завжди нескінченна» 25 .

Підсумовуючи, можна вважати, що в сучасній науці актуалізується образ Hото simbolicum (В. Ільїн ${ }^{26}$ ), для якого символічні форми відіграють роль найпотужніших архетипів, залучаючи особистість не до того, що вже є, а до того, що має бути. Символ був і залишається тим, що покликане привести людину до втраченої цілісності. Його визначають як:

- «інструмент залучення Таємниці» (Л. Вітгенштейн);

- «покажчик на межі небуття» (О. Лосєв);

- «спосіб з'єднання двох реальностей» (А. Косарєв);

- «вимірювач глибини сенсу» (П. Тілліх).

У структурі символу визначальну роль набувають ті значення, які активізують «указівну», посередницьку функцію символу: «вертикаль», «вектор», «перспектива». Символ, згортаючи інтуїтивно-осягнену сутність явищ у семантичну єдність, є найважливішим механізмом сприйняття трансцендентних духовних сутностей. Отже, спираючись на філософські визначення, перейдемо до моделювання структури музичного символу.

\section{2. Символ як звучно-слуховий феномен}

Структура символу (як певної даності, яка предметно означує щзось, указуючи при цьому на вищий сенс), передбачає важливу умову своєї наявності - людину («Я-свідомість»), котра сприймає й розшифровує символ. Відносини діалогу, що виникають при цьому, покликані задіяти різні сфери свідомості, що означають різні способи освоєння дійсності.

Музичний символ - це передусім слуховий феномен. I як такий, він має володіти специфічно-музичним комплексом ознак. Серед них передусім назвемо інтонаційність (що створює «смислове поле», у межах якого резонує поняття); контекстуальні зв'язки й наявність умов (семантизація музичної мови) для осягнення символу Іншим слухачем.

25 Лосев А.Ф. Знак. Символ. Миф. Москва, 1982. С. 447.

26 Ильин В. Теория познания. Символология. Теория символических форм. Москва : Изд-во Моск. ун-та, 2013. 384 с. 
Складність проблеми символу в музичному мистецтві полягає в тому, що пошук повинен здійснюватися в категоріальному вимірі самої музичної науки. У зв'язку 3 цим наведемо думку Є. Шевлякова: «У чому відмінність музичного символу від музичного образу? В особливій закріпленості за якимось музичним зворотом спеціального значення? У вгадуванні за цим значенням великої смислової «стереоскопії» і вглиб, і вшир, як у магічному кристалі? Якщо символ у своїй семантиці настільки багатозначний, що $\epsilon$ принципово непізнаваним, то чи не $\epsilon$ оперування цим терміном просто відходом від спроби зрозуміти специфіку того чи іншого творчого явища?» ${ }^{27}$ Автор попереджає, що, оскільки символ належить до багатозначних смислових конструкцій, то «остаточних істин може й не бути» ${ }^{28}$. I все ж спробуємо уособити властивості й функції символу в структурі музичного твору 3 урахуванням взаємодії 3 іншими змістоутворювальними категоріями музичної творчості.

Інтонаційність. Який зв'язок між інтонацією, чином і символом? Наприклад, у чому відмінність мотиву «хреста» від образу хреста i символу?

На особливу увагу при аналізі відносин «мотив-образ-символ» заслуговують теми-монограми. Володіючи інтонаційної визначеністю (авторство, ім'я), вони наче минають ланку образної редукції, одразу ж резонуючи на зв'язок із носієм символу (людиною, явищем природи тощо).

Насамперед музичний символ пов'язаний із комплементарністю слухових і зорових вражень. Очевидно, що символу для його існування необхідна не тільки інтонаційність, а й закріплена за нею знаковість, Музичний знак, що перетворюється на символ, набуває іншої смислової значущості. Ясно, що мотивна визначеність лише задіє галузь зоровослухових асоціацій для відтворення образної сфери: так, мотив «Dies irae» включається в образ року і смерті, будучи семантичним знаком, за яким стоїть традиція показу образу смерті. Секвенція «Dies irae» багатовіковий символ смерті і страшного суду - у музиці втілюється у варіантах від ледве чутних затаєних «кроків долі» до фантасмагорії; іiі неможливо пов'язати 3 одним емоційним полюсом. В авторській свідомості слуховий образ (інтонації скорботи) й образ візуальний (геометричний «малюнок» хреста) виявилися злиті воєдино. Або, наприклад, образ безмовності, тиші часто створюють паузи, образ інобуття - приглушена динаміка, ефект постійно вібруючого простору.

27 Шевляков Е. Блеск и нищета метафоричности в музыкознании. Памяти учителей. Ростов-на-Дону : Изд. Ростовского гос. педуниверситета, 1995. С. 26.

${ }^{28}$ Там само. 
Але не можна назвати паузу символом мовчання. Отже, у музиці художній образ перетворюється на символ, але визначити шлях цього перетворення виявляється надзвичайно складним.

Сформовані смислові атрибути категорії відображають усе те, що задіє символ у музиці: символ $є$ й інтонаційна структура, й образ (але образ n-ступеня, у своїх граничні можливості), і знак (але знак, який виходить за межі свого визначення), і дія як подія, що розвертається в просторі й часі. Однак символ не дорівнюе жодному 3 них, бо в кінцевому підсумку виявляється, що всі названі категорії $€$ його складниками, які згортає в собі вищий рівень, синтезує рівень символу як цілого (смисл). Символ виявляється «на вершині» ієрархічної структури музичного сенсу та виявляє себе як модель пережитого свідомістю досвіду. Інтонаційність є лише часткою цієї моделі, що важливо для музичної символіки (Dies irae, «крест», lamento etc).

Смислове поле й контекстуальні зв'язки. Теорія музичного символу безпосередньо пов'язана $з$ феноменом музичного сенсу. У більшості випадків музичний сенс оцінюється як моделювання, осмислення й узагальнення подій музичного твору. Важливо враховувати, що музичний сенс включає в себе не тільки якусь даність, а й водночас завжди $\epsilon$ новою даність, що раніше не існувала і поза музичного твору не існуючу. Аналогічні ідеї висловлював й С. Яроцінський. Він пише: «Символ у мистецтві - це вектор сенсу, який указує напрям <... Багатозначність і динамічний характер символу робить його близьким до поняття архетипу К. Юнга» ${ }^{29}$.

Символ, будучи результатом синтезу мистецтв i сегментом культури, у конкретному творі стає проявом авторської фантазії і волі, установки автора на «домовленість» зі своїм слухачем (за В. Холоповою). Можна стверджувати, що будь-яка символічна структура - це модель психічної діяльності свідомості автора: вона «автороцентрична» й містить знання про сутність його духовної діяльності, світовідчуття. У дослідженні К. Свасьяна знаходимо важливий для музикознавчого осмислення символу розподіл значень «символу-знаку», «символу-образу», «символу-поняття». Означаючи їх «символічними формами», автор указує, що «символ $є$ модальною категорією та проявляється в знаку як такому гіпотетично. Символ $\epsilon$ потенція знака, що може в ньому актуалізуватися; принципово ж символ не можна звести до знаку» ${ }^{30}$. У випадку з образом символ $\epsilon$

29 Яроцинский С. Дебюсси, импрессионизм и символизм. Москва : Прогресс, 1978. C. 52.

${ }^{30}$ Свасьян К. Проблема символа в современной философии (Критика и анализ). Ереван : Изд-во АН АрмССР, 1980. С. 40. 
«виглядом ідеї, який надає образ», а образ є лише «способом сходження» до ідеї» ${ }^{31}$. 3 релігійної культури походять розуміння причини, мети та шляхів появи символів. Так, причина появи символічного сенсу - зміна ставлення людини до Божественної дійсності. Мета появи символу - спонукання до розкриття «коду», пізнання сенсу. Шлях до символу - через переживання сенсу.

Відзначимо, що релігійна іпостась символу знаходить у музичному мистецтві найбільш багатогранне втілення, оскільки семантика музично-лексичних засобів у співвіднесенні із символами релігійними формувалися протягом багатовікового буття сакральних жанрів. За твердженням Г. Орлова, «вертикальний вимір духовності $\epsilon$ універсальним: це $<\ldots>$ сублімація досвіду буття у фізичному світі, у якому ми відчуваємо й долаємо сили земного тяжіння <..> Із цього універсального досвіду народжуються поетичні, духовні та релігійні метафори, алегорії та символи» ${ }^{32}$.

Музичний смисл $\mathrm{i}$ проблема його розуміння перебувають $\mathrm{y}$ комунікативній системі «автор-виконавець-слухач». В. Суханцева вважала музичний смисл універсалією, «суб'єктивним інобуттям у культурі», тому що він «наданий у ставленні до буття Іншого й через це ставлення. Будь-який сенс відповідає у своєму перебігу формулою «Своє-Інше», і культуротворча амплітуда сенсу коливається та зберігається саме в постійному перетіканні цих сутностей, не зводячись до жодної з них. Культурні потенції сенсу полягають у його затребуваності, у необхідності засвоєння будь-якого феномена» ${ }^{33}$.

Завдяки накопиченому досвіду у філософії мистецтва, новітнім дослідженням з теології і культурології маємо можливість для введення в науковій обіг поняття «метафізичний вимір» символу. Ця сфера досвіду (пізнання Таємного як метафізичне) у проаналізованих галузях гуманітарного знання явно позначена. Основне завдання когнітивного аналізу полягало в тому, щоб обгрунтувати необхідність введення «метафізичного» виміру символу в концептосферу музикознавства. Унаочнимо інваріантну структуру символу в музиці як систему трьох рівнів (вимірів) (таблиця 1).

${ }^{31}$ Свасьян К. Проблема символа в современной философии (Критика и анализ). Ереван : Изд-во АН АрмССР, 1980. С. 40.

${ }_{32}$ Орлов Г. Древо музыки. А. Frager \& Co, Вашингтон СПб. : Композитор, 1992. 408 c.

${ }^{33}$ Суханцева В. К. Музыка как мир человека (от идеи вселенной - к философии музыки). Киев : Факт, 2000. С. 57. 
Таблиця 1

Структура музичного символу

\begin{tabular}{|c|c|c|}
\hline $\begin{array}{c}\text { Художній } \\
\text { (досвід творчості) }\end{array}$ & $\begin{array}{c}\text { Фізичний } \\
\text { (акустичне } \\
\text { звучання) }\end{array}$ & $\begin{array}{c}\text { Метафізичний } \\
\text { (розуміння сенсу } \\
\text { при спілкуванні) }\end{array}$ \\
\hline Можливості: незакінченість, & Способи & Посередницька \\
інтерпретативність; «подвійний & об'єктивації; мовна & функція як \\
простір», інверсія, & предметність; & умова \\
взаємозворотність, & синтаксис; тембр; & спілкування/ \\
енергія/синергія; двосвіття ${ }^{34}$ & звуконаслідування & пізнання \\
\hline
\end{tabular}

Відмінності, зазначені в таблиці, умовні й стосуються способів буття: «фізичне» - це звучні об'єкти реального світу, «художнє» авторське бачення реального світу, зафіксоване в художньому тексті; «метафізичне» - досвід сприйняття таємниці. Символ, який пізнається через досвід творчості, вимагає неодмінної спрямованості на людину. Складники системи «Таємниця-символ-Я» взаємозалежні та зворотні залежно від того, чий досвід первинний: Автора (тоді система «Таємниця-символ-Я») або слухацька, «Я-свідомість» (тоді послідовність така: «Я-сприйняття»-символ-Таємниця»).

Варто пам'ятати, що всі три виміри існують завдяки співвіднесеності критеріїв їх пізнання в систему через дію законів: а) онтологізму; б) цілісності. Структура символу, що осмислена через триєдність фізичного, художнього та метафізичного, водночас становить виміри іншої (прихованої) реальності, яка відкривається реципієнту (слухачеві, глядачеві, читачеві) через художній твір і стає його внутрішньою реальністю. Отже, через семантизацію музичної мови та наявність символічної реальності музикант $є$ співтворцем духовного буття, а всяка інтерпретація музичного твору перетворює вже наявну духовну реальність.

\section{ВИСНОВКИ}

Пропонований когнітивний аналіз інтерпретації символу як концепту гуманітарних наук і музикознавства підтвердив, що, дійсно, кожна наука займається з'ясуванням «поступового різноманіття символу», за виразом філософа К. Свасьяна. Позначимо загальні та відмінні тези теорії символу в контексті філософсько-гуманітарного інтерпретування й музикознавчих інтенцій:

34 «Рефлексивна творчість є відбитком (подвоєнням) цілокупного буття... I в цьому сенсі музика $є$ аналогом людини», за виразом Л. Шаповалової. 
1. Відмінність між символічною ідеєю, образом у музиці й власне музичним символом надзвичайно велика. Загалом можна зробити висновок, що образ є більш ширшою категорією, але, щоб конкретний образ набув статусу символу, потрібні певні умови цього осягнення.

2. Позначимо ті значення в богословської концепції символу, які необхідні нам для створення його інваріантної структури. 1) Символ не дорівнює собі, бо перевершує себе. 2) Символ є часткою Божественного; щоб його пізнати, необхідний особистісний досвід у Богоспілкуванні. 3) Символ є діалогічним. Осягнення Я-свідомістю релігійного дискурсу символу становить таїну одкровення. Богословський дискурс додав до пізнання символу якість «особистого досвіду». «Досвідченість» Я, що сприймає й переживає сенс символу, є наріжним каменем екзистенції символаріуму музичного мистецтва, як релігійного, так і світського.

3. Структура символу з погляду пізнаваності є системою 3 3-х рівнів (умовно «художній», «фізичний» і «метафізичний»). Символ як даність предметно означує щось, передбачаючи наявність Я-свідомості, яка приймає і розшифровує його сенс. Відносини діалогу, що виникають при цьому, покликані задіяти різні сфери Я-свідомості: розумову (здатність читати «культурний код», мислити в системі символів мистецтва) та інтуїтивно-цуттєву (особистісний досвід сприйняття того, що знаходиться поза символом). Нарешті, символ як «динаміка сенсу», «діалогічна форма знання» (С. Аверінцев) передбачає такі когнітивні передумови: установку на свідомість (К. Юнг); «релігійну ситуацію» (П. Тілліх), внутрішню роботу сприйняття й переживання сенсу (Августин); культурний контекст, «культурний код» (Р. Барт), типи знання; суб'єктність творчого акту (можливість виробляти символи, «помножувати» через авторську мову).

4. Символ - певний зразок, тип, який $є$ частиною Іншого (невидимого) світу; він самодостатній, але перевершує себе. Щодо музики ці якості, які заперечують одна одну, більше ніж зрозумілі: за конкретним звуком завжди стоїть над-рівень, зміст, заради якого звук був здобутий. Властивості символу можна теж увиразнити через антиномії: він нетразинтивний, але інтенціональний; мотивований, але утаємнений; прозорий, однак «незакінчений»; моментальний, але розгорнутий у часі. Отже, сенс символу цілісний, але множинний; зашифрований i розшифрований водночас; точний, а може, й імовірнісний.

Залишаючись стійким у своєму значенні й водночас розвиваючись разом із людиною, символ $є$ перспективою для постійного виявлення в ньому нових і нових смислових граней. 


\section{АНОТАЦІЯ}

Пропонується досвід систематизації наукових підходів до вивчення символу з авторським коментарем, актуальний для сучасного музичного мистецтва. Музикознавство має у своєму розпорядженні весь спектр смислів, серед яких - класична семіотика (Ч. Пірс, Ф. де Соссюр), психологія (К. Юнг), філософія (О. Лосєв, П. Флоренський), поетика літератури (Й. Гете, Ф. Шиллер, французькі й російські символісти), культурологія (Ц. Тодоров, С. Аверінцев). Кожна наука займається 3'ясуванням «поступового різноманіття символу» (К. Свасьян). Мета статті - узагальнити когнітивний досвід вивчення художньої природи символу. Це можливо на основі порівняння інваріантної структури символу з позицій різних галузей гуманітарного знання про людину (богослов'я, літератури, філософії, культурології). Запропоновано різні дефініції категорії «символ» у динаміці співвідношення різних аспектів проблеми символу: символ як поняття й художня реальність, символ як музично-слуховий феномен; механізми функціонування релігійного символу. Розрізняються рівні пізнаваності символу у філософському значенні: а) причини появи (генеза) і призначення; б) структура символу; в) межі сенсу. Принцип відбору різних дефініцій зумовлений надзавданням визначити ступінь пізнаваності символу в культурі, щоб у подальшому спроектувати константні ознаки й функції символу як об’єкта духовної культури на музичний твір.

Структура символу 3 погляду пізнаваності $є$ системою 3 трьох вимірів (умовно «художній», «фізичний», «метафізичний»). Символ як даність предметно означує що-небудь, передбачає наявність Я-свідомості, яка приймає і розшифровує символ. Відносини діалогу, що виникають при цьому, покликані задіяти різні сфери «Я»: розумову (здатність читати «культурний код», мислити в системі символів мистецтва); інтуїтивно-чуттєву (особистісний досвід сприйняття того, що знаходиться поза символом).

\section{SUMMARY}

The experience of the systematization of scientific approaches to the study of the symbol with the author's commentary is offered. Contemporary musicology has a full spectrum of meanings, including classical semiotics (C. Pierce, F. de Saussure), psychology (C. Jung), philosophy (A. Losev, P. Florensky), poetics of literature (J. Goethe, F. Schiller, French and Russian Symbolists), cultural studies (Ts. Todorov, S. Averintsev). Each science is engaged in the elucidation of the "gradational diversity of the symbol" (K. Svasyan). 
The purpose of the article is to summarize the cognitive experience of studying the artistic nature of the symbol. This is possible on the basis of comparing the invariant structure of the symbol from the standpoint of different areas of humanitarian knowledge about Human (theology, literature, philosophy, and cultural studies).

Various definitions of the "symbol" category have been proposed in the dynamics of the correlation of different aspects of the symbol problem: the symbol as a concept and artistic reality, the symbol as a musical and auditory phenomenon; mechanisms of functioning of a religious symbol; the cognizability of the symbol. The problematic situation that has developed in the latest science, associated with the actualization of the category of "awareness", with the mobility and reversibility of the connection between the signifier and the signified, is noted. This, in turn, is caused by the influences of various sciences (hermeneutics, psychology, psychoanalysis, theology, philosophy, and genetics) on the enrichment of certain methodologies (including the musical science).

The article distinguishes the levels of cognizability of the symbol in a philosophical sense: a) the reasons for the appearance (genesis) and purpose; b) the structure of the symbol; c) the boundaries of meaning; The principle of selection of various authors and definitions is stipulated by the task of determining the degree of cognizability of the symbol in culture, in order to further project individual signs and functions of the symbol as an object of spiritual culture onto music. Modern philosophy has come to the conclusion that if the symbol always presupposes awareness, then the sign means "a stop of awareness" (M. Mamardashvili). The process of comprehending symbolic forms in art presupposes several positions (V. Ilyin, M. Heidegger), including: interactivity (symbolism is certified by communication); transreality (since the symbols translate the concrete into the abstract and the particular into the typical); supra-individuality (going beyond the boundaries of "self"); expressibility (since "the thinking thinks in images" - Aristotle); hermeneuticity (Human is being unfolded fourfold - by four basic symbols as the interpretative archetypes of existentiality: salvation of the earth, perception of heaven, expectation of the divine, seeing off the mortal - M. Heidegger), polysemy (the plurality of the symbolic is a consequence of its polyfundamentality); motivation, spirituality ("a human is never a complete imperfect" - V. Ilyin); creativity (the symbol is always a projection of the real on the background of the possible, open to infinity).

The article analyses the "religious situation" - a term that explains the emergence of new symbols and the loss of old ones. The "religious situation" is generated by a change in a human's attitude to God (a change in 
experience!), which is reflected in religious symbolism. In turn, these symbols make it possible for a human to cognize the immeasurable depth of the Divine. Theological discourse added to the cognition of the symbol the category of "personal experience" of the perceiver. To think in symbols means to endlessly discover new meanings, to continuously "perform sacred acts" (Augustine).

Based on the aforementioned, the symbol is presented as a semantic reality (in contrast to the sign, which is a denoting reality). There is the actualization of the image of Homo simbolicum, for whom symbolic forms play the role of the most powerful archetypes, attaching a human not to what is, but to what should be.

Musicological discourse of the concept is associated with a pair of "signsymbol" and "symbol-cognition". For example, G. Orlov establishes three essential differences of a musical sign (from the sign of linguistic and nonlinguistic communications): it belongs to the category of individual; characterized as unique; is a sign of unconditional meaning, revealing in perception its unquestionable involvement in the designated content.

The structure of the symbol in the author's concept is a system of three dimensions: conventionally "artistic", "physical" and "metaphysical". The three dimensions exist owing to the correlation of the criteria of their cognition into the system through: a) ontology; b) integrity. The dimensions of the symbol, which we consider as its structural projections, are the dimensions of that hidden other reality that is revealed to the recipient (listener, viewer, and reader) through the work of art and becomes its inner reality.

The symbol as a given, which outlines something objectively, presupposes the presence of I-Awareness, which perceives and deciphers the symbol. The relations of the dialogue that arise in this case are called upon to involve different spheres of "I": the intelligent sphere (the ability to read the "cultural code", to think in the system of the symbols of art); the intuitive-sensual sphere - the personal experience of perceiving what is outside (beyond) the symbol.

\section{ЛITЕРАТУРА}

1. Августин Б. Христианская наука или основания герменевтики и церковного красноречия. Киев, 1835 (репринт). 355 с.

2. Аверинцев С. Символ. София-Логос. Киев, 2001. С. 155-161.

3. Асафьев Б. Музыкальная форма как процесс. Ленинград, 1971. 2-е изд. $376 \mathrm{c.}$

4. Барт Р. Воображение знака. Избранные работы: Семиотика: Поэтика. Москва, 1989. С. 246-253. 
5. Барт Р. Риторика образа. Избранные работы: Семиотика: Поэтика. Москва, 1989. С. 297-319.

6. Белый А. Символизм как миропонимание. Москва : Республика, 1994. 548 с.

7. Вакенродер В.-Г. Фантазии об искусстве. Москва : Искусство, 1977. $265 \mathrm{c}$.

8. Витгенштейн Л. Человек и мыслитель. Москва : Прогресс Культура, 1993. 351 с.

9. Гете И. Избранные философские произведения. Москва, 1964. $429 \mathrm{c}$.

10. Губайдулина С. «Дано» и «задано». Музыкальная академия. 1994. № 3. С. 1-7.

11.Ильин В. Теория познания. Символология. Теория символических форм. Москва : Изд-во Моск. ун-та, 2013. 384 с.

12. Кант И. Критика способности суждений. Кант И. Сочинения : в 6 т. Москва : Мысль, 1964. Т. 5 / пер. Н. Соколова. 564 с.

13. Косарев А. Философия мифа. Мифология и ее эвристическая значимость. Москва : Университетская книга, 2000. 298 с.

14. Лангер С. Философия в новом ключе: Исследование символики разума, ритуала и искусства / пер. с англ. С.П. Евтушенко ; общ. ред и послесл. В.П. Шестакова. Москва : Республика, 2000. 287 с.

15. Леві-Строс К. Структурна антропологія / пер. 3 фр. 3. Борисюк. Київ : Основи, 1997. 387 с.

16. Лосев А.Ф. Знак. Символ. Миф. Москва, 1982. 480 с.

17. Лосев А. Проблема символа и реалистическое искусство. Москва, 1995. 320 с.

18. Лотман Ю.М. Символ в системе культуры. Избранные статьи : в 3 т. Таллинн : Александра, 1992. Т. 1 : Статьи по семиотике и типологии культуры. С. 191-200.

19. Мамардашвили М.К., Пятигорский А.М. Символ и сознание. Метафизические рассуждения о сознании, символике и языке. Москва : Языки русской культуры, 1997. 217 с.

20. Медушевский В.В. О закономерностях и средствах художественного воздействия музыки. Москва : Музыка, 1976. 254 с.

21. Медушевский В.В. Как устроены художественные средства музыки? Эстетические очерки. Москва : Музыка, 1977. Вып. 4. С. $79-114$.

22. Назайкинский $\mathrm{E}$. O психологии музыкального восприятия. Москва, 1972. 383 с.

23. Ніколаєвська Ю.В. Ноmo interpretatus в музичному мистецтві XX - початку XXI століть. Харків : Факт, 2020. 576 с. 
24. Орлов Г. Древо музыки. А. Frager \& Co, ВашингтонСанкт-Петербург : Композитор, 1992. 408 с.

25. Свасьян К. Проблема символа в современной философии (Критика и анализ). Ереван : Изд-во АН АрмССР, 1980. 226 с.

26. Символ. Філософський енииклопедичний словник. Київ : Абрис, 2002. C. $578-579$.

27. Суханцева В.К. Музыка как мир человека (от идеи вселенной к философии музыки). Киев : Факт, 2000. 175 с.

28. Тиллих П. Теология культуры. Избранное: Теология культуры / пер. с англ. О.В. Боровой. Москва, 1995. С. 236-395.

29. Тодоров Ц. Теории символа. Москва : Дом интеллектуальной книги, 1999. $384 \mathrm{c.}$

30. Флоренский П. У водоразделов мысли. Собрание сочинений : в 2 т. Москва : Правда, 1990. Т. 2. 439 с.

31. Холопова В.Н. Музыка как вид искусства. (Музыкальное произведение как феномен). Москва : Планета искусства, 2004. 320 с.

32. Шаповалова Л.В. Рефлексивный художник. Проблемы рефлексии в музыкальном творчестве. Харьков : Скорпион, 2007. 272 с.

33. Шафф А. Введение в семантику / пер. с пол. М.Я. Гловинской, Н.Г. Комлева, В.Ф. Конновой. Москва : Изд-во иностранной литературы, $1963.376 \mathrm{c.}$

34. Шевляков Е. Блеск и нищета метафоричности в музыкознании. Памяти учителей. Ростов-на-Дону : Изд. Ростовского гос. педуниверситета, 1995. С. 20-27.

35. Шеллинг Ф. Философия искусства. Москва : Мысль, 1966. 496 с.

36. Шкуратов В. Историческая психология. 2-е изд. Москва, 1997. $505 \mathrm{c}$.

37. Юнг Г. Человек и его символы. Москва : Renais, 1991. 297 c.

38. Юнг Г. Психологические типы. Москва, 1996. 637 с.

39. Яроцинский С. Дебюсси, импрессионизм и символизм. Москва : Прогресс, 1978. 232 с.

40. Brandt A., Carmo Jr., José R. Music and Meaning. Signata. 2015. V. 6. P. 15-21. URL: https://doi.org/10.4000/signata.1382 (дата звернення 20.02.2021).

41. Beyer K., Eraser C. Speech as a marker of situation. Sosial markers in speech. Cambridge Paris, 1978. P. 33-62.

42. Cooke D. The language of music. Oxford, 1959. $230 \mathrm{p}$.

43. Lissa Z. O tzw. rozumieniu muzyki. Nowe szkice $z$ estetyki muzycznei. Krakow, 1975. S. 26-52.

44. Meeús Nicolas. A semiotic approach to music. Contemporary Music Review. 1993. V. 9. Is. 1-2 : Music and Cognitive Sciences. P. 305-310. 
45. Nattiez J.-J. Musicologie generale et semiologie. P. : Christian Bourgois, 1987. $400 \mathrm{p}$. URL: http://svictor.net/anthropology/varia / 23-teaching /33-nattiez (дата звернення 20.02.2021).

46. Reybrouck Mark (August 23rd 2017). Music and Semiotics: An Experiential Approach to Musical Sense-Making. Interdisciplinary Approaches to Semiotics, Asuncion Lopez-Varela Azcarate, IntechOpen. URL: https://www.intechopen.com/books/interdisciplinary-approaches-tosemiotics/music-and-semiotics-an-experiential-approach-to-musical-sensemaking (дата звернення 20.02.2021).

47. Tarasti E. A Theory of Musical Semiotics. Indiana University Press, 1994. $352 \mathrm{p}$.

Information about the authors: Nikolaievska Yu. V.,

Candidate of Art History, Associate Professor, Associate Professor at the Department of Interpretology and Music Analysis Kharkiv I. P. Kotlyarevsky National University of Arts 11/13, Constitution sq., Kharkiv, Ukraine

Shapovalova L. V., Doctor of Art History, Professor, Head of the Department of Interpretology and Music Analysis Kharkiv I. P. Kotlyarevsky National University of Arts 11/13, Constitution sq., Kharkiv, Ukraine 